\title{
URBAN SOLID WASTE GENERATION, DISPOSAL, TREATMENT AND TRANSFORMATION - A CASE STUDY OF BANGALORE
}

'Pallavi M Vishwanath, ${ }^{2 D r}$.Akshey Bhargava

1 Assistant Professor, Sir M.V School of architecture, VTU University Bangalore, India

2Ex. Rajasthan Pollution Control Board, CEPT University, India

Email id: 1ar.pallavi25@gmail.com,2draksheyb@gmail.com

\begin{abstract}
As urban cities grow bigger, the per capita generation of waste also increases proportionately. The rate at which the urban cities grow is so rapid that they make the collection of all the waste and procuring the land for treatment and disposal more difficult. But managing the urban solid waste plays a significant role in the efficient functioning of the cities. Waste management is generally administered with limited resources and limited capacity by local authorities. The data pertaining to waste management makes it easier to predict the associated future challenges with the help of other factors like economic development and population growth. This knowledge helps the local governing bodies to design a suitable system to tackle municipal solid waste. This paper aims to share the technological trends associated with the solid waste generation and its transformation hoping to improve waste management situation in India.
\end{abstract}

Keywords: Urban, solid waste, disposal, treatment, emerging trends, management, economics 


\subsection{Introduction:}

The world generates 2.01 billion tonnes of municipal solid waste annually, with at least 33 percent of that - extremely conservatively not managed in an environmentally safe manner. Worldwide, waste generated per person per day average 0.74 kilogram but ranges widely from .11 to 4.54 kilograms. (Group, 2018 ). In India, municipal solid waste management in the country has emerged as a challenge not only because of the environmental and aesthetic concerns, but also because of the huge quantities of municipal solid waste (MSW) generated every day. According to central pollution control board 1,43,449 tonnes per day (TPD) of MSW was generated of which only approximately 1,17,644 TPD ( $80 \%$ ) was collected, while only 32,871 TPD (22\%) was processed or treated. (development, 2016). Bangalore is also one of the cities facing the same issue and constantly battling with it. Bangalore being an urban city, where land is scarce becomes a major challenge to fulfil this requirement. Adding to this is the exponential growth in the population in the city which makes it even harder. There was one time in 2012 , when the issue crossed all the thresholds by piling up the garbage on the streets and footpaths continuously for days. During this period, the tag of garden city given to Bangalore changed to garbage city. This huge development occurred due to closure of the Mavallipura landfill site on $11^{\text {th }}$ July 2012 from Karnataka statepollution control board (KSPCB). The climate of Bengaluru being very moderate, the rates of decomposition of organic waste is slow.
The issue of SWM is very peculiar type of an issue where one needs to find the land to dispose the waste, but at the same time needs constant check as to not spread the toxicity through land or water beneath the waste. In this context, it is necessary to reduce the waste reaching the final disposal in large quantities. Hence there is a need to study current practice of primary collection system of solid waste management in Bangalore and suggest ways to achieve the objective of waste reduction.

Henry et al (2006) studied the MSWM of Kenya, which is a low-income developing country. The improper and unplanned dumping of the wastes by the citizens of the country on the river banks and roads has resulted in the environmental and economic problems to the nearby places. The increasing urbanization, inadequate availability of the collection vehicles and poor management of waste disposal are certain factors which have made the planning of the waste management the need of an hour in such developing nations (4). Mumbai is one of the largest metropolitan cities in India and hence the amount of waste is proportional to the population of the city. Sarika (2006) suggested two major alternative methods that can be incorporated for a better management in the disposal of waste. Public private partnership and community participation are the two suggested alternatives out of which the most viable and the economic is the one which involves community participation in the management of the waste (5).On the other hand various developed nations such as Japan and USA have analysed the problem and found pragmatic solutions to it in 
comparison the developing and the under-developed nations. The changes in the strategy over a time period and adoption of recycle, reuse and renew policy have resulted in this change. Nevertheless, India yet has to develop some comprehensive structure for the management of the solidwaste (6).The present study gains importance as it considers the enormous waste production in the Kanpur city and hence, the need of the sustainable and economic waste management system in the city.

\subsection{Sources of municipal solid waste:}

The Municipal Solid Waste (MSW) consists of organic and inorganic waste materials generated from households, nonhazardous solid waste which is discarded by the industrial , commercial, and institutional establishments. It also includes market waste, yard waste, and street sweepings collected by the municipal authorities(jain, 2007). Waste that arise from a typical urban society comprises of garbage, rubbish( package materials), construction and demolition wastes, leaf litter, hazardous waste, etc.(R.Rajput). The biodegradable waste is about $55-60 \%$ matter. Thisbiodegradable waste can be converted into manure. Recyclablematerials such as paper, cardboard, glass, metal, plastic, electronic is $16-25 \%$ and used for recycling purpose. 15\% of inert materials will goto landfill. These percentages differ from city to city to city dependingupon food habits. Also it has been noted that the characteristics of thewaste are undergoing changes with time. Modern urban living brings on the problem of waste because of everything in packaging and fast food, which increases the quantity of waste and changes its composition with each passing $\operatorname{day}(\mathrm{Vij}, 2012)$. The improper disposal of MSW pollutes all the vital components of the living environment, i.e., air, land, and water.

\subsection{Present waste management scenario in Bangalore:}

Presently, the Bruhat Bangalore MahanagaraPalike (BBMP), the agency vested with responsibility of collection and disposal of solid waste, is engaged in a series of approaches such as involvement of citizen, investment in infrastructure and technology, as well as monitoring the various systems that are involved in managing the present mix of actions and techniques. For a more efficient andeffective approach, BBMP has been divided into different administrative units. There are 294 Health wards within the BBMP. Presently, in Bengaluru there are 198 such administrative or political wards. Within the BBMP, there are two departments which are directly involved in municipal solid waste management; they are Health

Department and Engineering Department. The health Department is mainly responsible for collection, transportation and disposal of solid waste. The Engineering Department is responsible for the removal of construction and demolition waste, whilst they also provide technical and infrastructural support to the health department.

\subsection{Waste generation \& management in Bangalore}


The total municipal solid waste has increased from 650 tpd to about $3600 \mathrm{tpd}$ in 2010. The total waste generation in 2012 was $4650 \mathrm{tpd}$. The following is the percentage of waste generated from various categories

- Households - 54\%

- Markets and function halls - 20\%

- Commercial establishment \& institution $-17 \%$ \& others $-9 \%$

\subsection{Collection Of waste:}

Primary collection of waste -

- $\quad$ is using 11000 pushcarts \& 650 auto tippers

- Around 4300 pourakarmikas of BBMP and 10000 pourakarmikas from contractors used for door to door collection \& sweeping activities.

At present, Bengaluru can handle the municipal solid waste of about 2100 TPD only. The existing capacity of a waste treatment facility at Mavallipura is 600 TPD, Karnataka Composting Development Corporation Ltd (KCDC) is 300 TPD, and Terra Firma is about 1500 TPD. To achieve 100\% processing of waste in Bengaluru, Government has sanctioned six new facilities. These new facilities are being set up at the following locations: Kannahalli is 500 TPD, Seegihalli is 200 TPD, Doddabidarakallu is 200 TPD, Lingaderenahalli is 200 TPD, Subrayanpalya is 200 TPD, Chikkanagamangala is 500 TPD, KCDC(upgradation) is 500 TPD. These are majorly wet waste composting plants with a provision to screen compost out of mixed MSW \&provision also to store the non-compostable/ non-recyclable materials. These materials can be used for coincineration in cement industries/power generation.

\subsection{Secondary collection \&transportation:}

- There are about 600 MSW transportation vehicles including compactors, tipper, lorries, dumper placers \& mechanical sweepers including BBMP and contractors

- The waste is collected from the households is brought to a common point ie secondary collection points( vacant site, road sides etc) from where it is shifted to the compactors and tipper lorries for transportation to the treatment and disposal sites.

\subsection{Schedule of collection of waste:}

- Collection of dry waste twice a week from each household and transported to the designated dry waste collection centre

- Sanitary waste separately collected and transported to the designated hospital/nursing home notified as sanitary collection centre

- Promote MSW segregation at household level through awareness campaigns and other suitable means.

- Wet waste and dry waste shall not be mixed either at the time of collection or transferring the same to processing site.

- The waste from shop keepers, vendor and street hawkers shall be compulsorily collected in segregated form without allowing 
them to throw the waste at untimely hours near the secondary storage points

\subsection{SWM Governance in Bangalore:}

In order to govern Solid waste management in Bangalore, BBMP has established a separate department to ensure public and environmental health of our city called the BBMP SWM cell.
Their main aim is to develop and implement a policy based on Solid waste management rules 2016, and integrated solid waste management. Also many events like closure of Mavallipura landfill site and protest by the villagers of Mandur have led to the directives being issued by the hon'ble high court of Karnataka which has further strengthened the will to implement the above said policies efficiently.

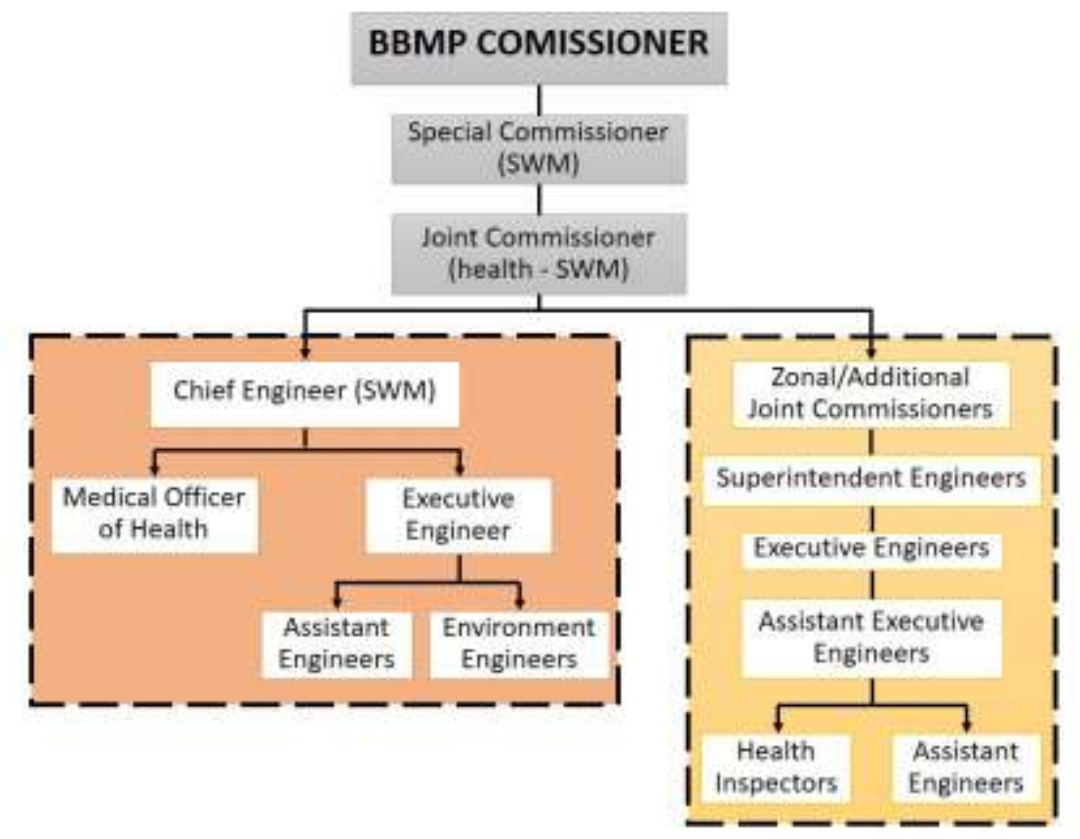

Fig 1. BBMP organisational structure

(Source- BBMP SWM official website, SWM informational manual_part I )

The new approach therefore aims at decentralised processing of waste by stream, bulk generators to manage their own waste, and creating a ward micro plan form management and execution of SWM services. Therefore the SWM cell has been aimed at two levels- At the head office and at the zonal level.

At the ward level, for easier management, each ward is split into blocks each which consists of 1750 households + small commercial units). These blocks have been allotted labour and vehicles to collect and transport the waste. Also, additional areas like street, roads have been classified into major, intermediate and minor roads with unique road ID.

All the data regarding the collection and transportation, needs to be filled in ward template, block data, and ward/block map which needs to be sent ot the head office.

\subsection{Other SWM initiative by BBMP}

\section{- Governance}

Apart from the conventional mode of governance, many apps have been designed to help the citizens and 
workers of the BBMP SWM cell to ensure an efficient Solid waste management. Few of them are -

- Biometric attendance app for daily attendance of the pourakarmikas(health workers)

- Clean Bengaluru app - for citizens to report and garbage related issues

- Shuchimitra app - a volunteering team to report the daily waste collection, along with photos of their respective blocks/wards.

- BG- NET( Bulk Generators NETwork) portal - where all the bulk generators report on how they manage waste and their selected list of vendors with whom they dispose the waste streams generated. This information is updated annually.

\section{- Dry Waste Collection Centres (DWCCs)}

The Dry waste collection centers are set up by BBMP for recycling the dry materials like plastic, paper, glass, metals, etc. There is a plan is to set up a DWCC in all the 198 wards. Till October 2013, 148 DWCCs have been set up, of which 100 are functional, out of these 57 DWCCs have been entrusted to NGOs.

\section{- KasaMukhtaProgramme}

This programme was launched on 24th July 2013. It is an at-source segregation initiative at ward level developed jointly by BBMP \& Wake Up Clean Up. It was launched on 24th July 2013 with a view to introduce destination bound processing of wastes and to be scaled City wide once the program is stabilized. The initiative was planned to start in 22 pilot wards.

\section{- Registration of Waste pickers - formal recognition of their role by BBMP}

Following the LokAdalat's directive in 2011, the BBMP Commissioner issued an official circular to register wastepickers and itinerant buyers and enumerate scrap dealer - the first step towards formal recognition of their role. On 9th August 2011, at the first Waste-pickers Convention, 200 wastepicker ID cards were distributed following the registration. As of 2013, the BBMP has distributed over 5000 ID cards and have sanctioned additional 7000 registrations.

\section{- Karnataka Compost Development Corporation}

KCDC was established in 1975, involved in eco-friendly treatment of city garbage and agriculture waste through production of compost based organic manure and vermi-compost by adopting aerobic decomposition windrow method.

- The plant was receiving $50 \mathrm{tpd}$ in the early years and it was set up to receive 200 tpd after its expansion program under Bangalore Mega City Scheme. From September 2008 onwards the receipt of garbage was stopped due to accumulation of untreated garbage.

- KCDC was revived in 2013 after five years of inaction. In June 2013, BBMP started sending KCDC around 100 tons of vegetable waste a day, from Madivala and city market. Currently it treats about 600tons of waste every day i.e 300 tons of the existing waste and 300 tons of segregated wet waste. 


\subsection{Transformation of waste into usable products:}

There are several technological options available and presently in use to transform waste into usable products in the form of compost, bio fuels, and energy. Some of these technologies in brief are described hereunder:

\subsection{Transformation of waste to compost:}

There are various technological options available for the conversion of the waste produced into the usable products. This conversion of the huge amounts of waste produced in the city is mandatory as it causes environmental as well as health issues. The various technologies available for composting are as follows:

- Closed Bins method

- Pit Composting Method

- Open Bins Method

- Tumblers Method

- Piling Method

- Vermicomposting Method

Out of the above listed methods, one method of open bin composting is being briefly described as under:

\section{- Open bins method:}

Open bins are structured area using wire fencing or wood to store organic matter which enable perform hot or cold composting. Such bins facilitate easy turning and harvesting of materials and for air to enter and circulate leading to fast decomposition. These bins are easy to build and can accommodate large volumes. The three-bin system is approximately 12 feet long and 4 feet wide with each compartment being 4 feet square as shown in figure 2(4).

\section{Advantages:}

- Simple to construct

- Holds large amounts of organic matter

- Good for hot composting

- Materials are tidy and partially hidden

- Easy to turn materials and harvest compost

- One-bin system fits in most areas

\section{Disadvantages:}

- Can be expensive

- Compost isn't completely hidden

- Three-bin system requires a lot of space

Figure: 2 showing three bin composting system

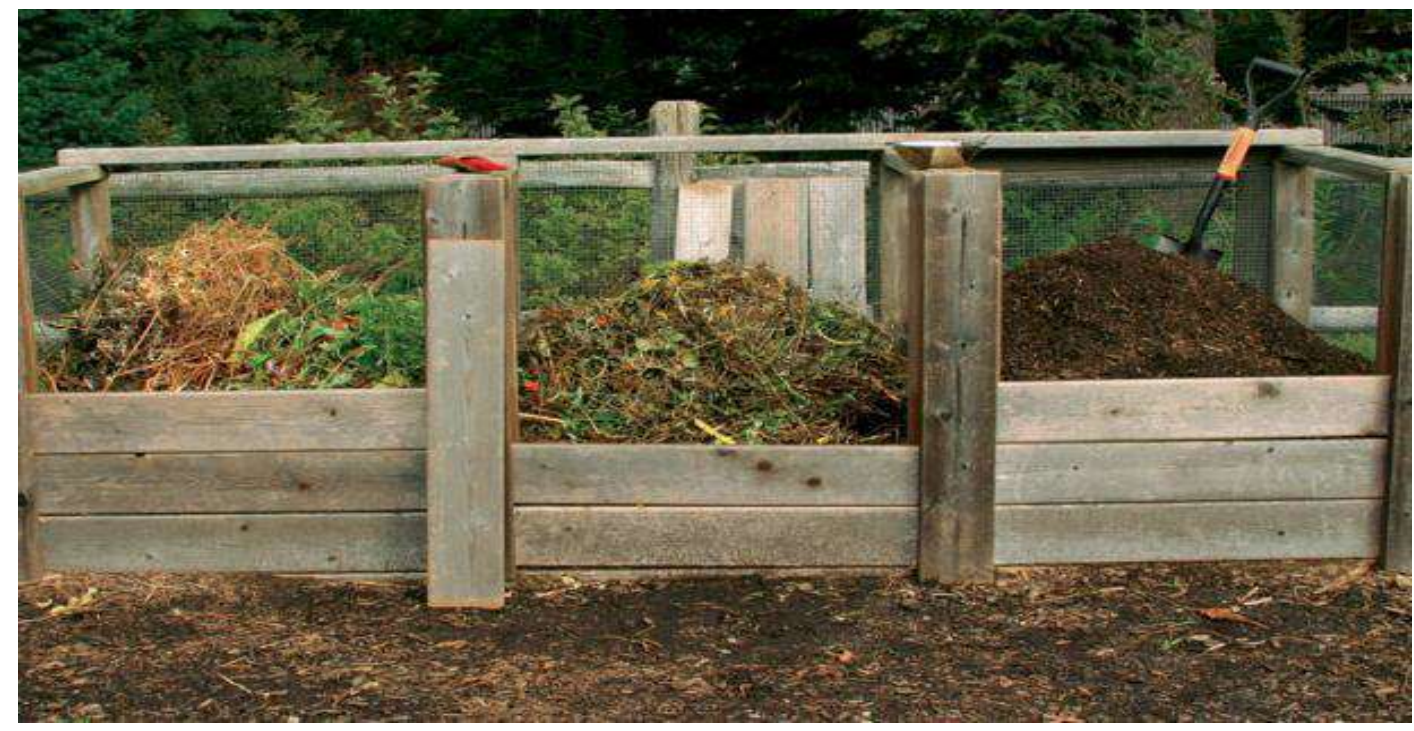




\subsection{Transformation of Waste to Energy:}

Waste-to-energy is a method where waste is used as a fuel for generating power in which waste material is received in an enclosed receiving area where it is thoroughly mixed before combustion and then negative airflow is provided to carry dust and odor into the combustion chamber from the receiving area. Subsequently, mixed waste is then fed into the combustion chamber through a moving grate which enables to turns it over repeatedly to keep it exposed and burning where oxygen and fumes drawn from the receiving area are injected to allow complete burn. The burning fuel heats water into steam that drives a turbine to create electricity. This process can reduce a landfill volume up to 90 percent and prevent one ton of carbon dioxide release for every ton of waste burned (9). The complete process of converting waste to energy along with environmental control measures are shown in figure 3 below:

Figure: 3 Shoring power generation from waste:

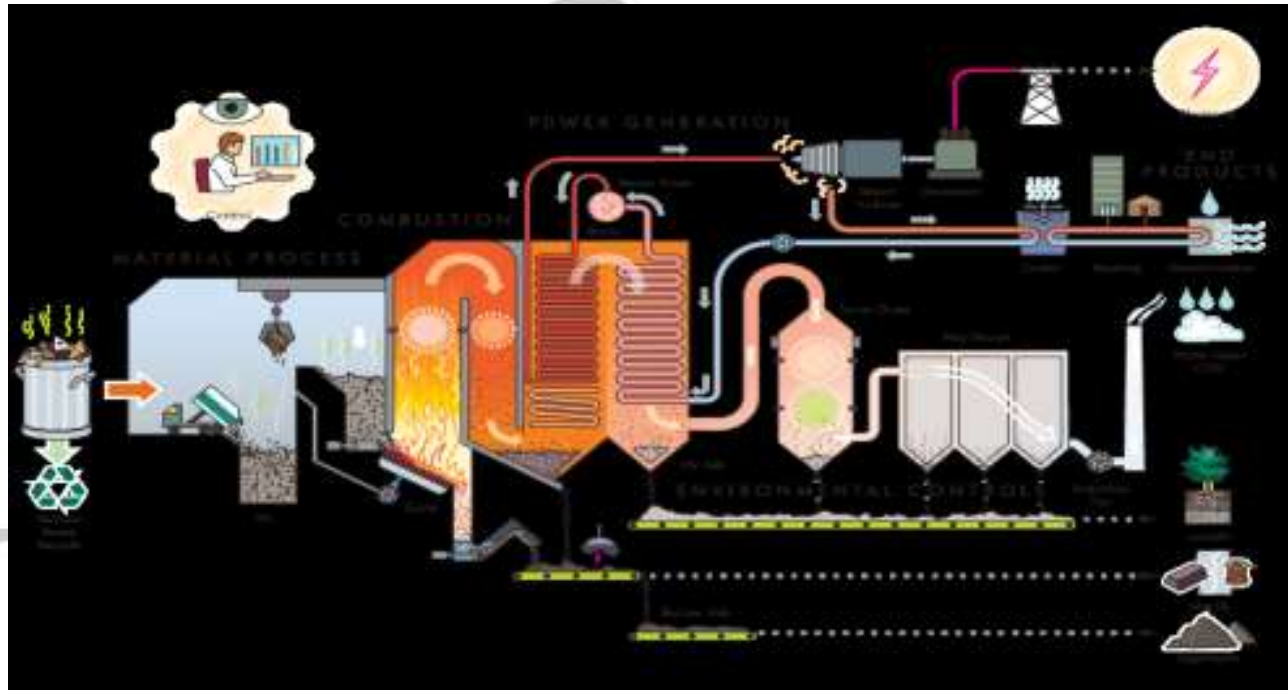

\subsection{Environmentally sustainable waste} management: A case study of Bangalore:

An attempt has been made to workout sustainable municipal solid waste management for the city of Bangalore, India. In the present context, the population trends with forecast of population for the year 2051 were estimated along with solid waste generation. An effort has also been made to estimate the quantity of compost, bio fuel and energy that can be produced from the generation of solid waste during different years. In order to have sustainability, economic dimension in terms of the possible financial cost of compost, bio fuel and energy were also estimated. The salient steps taken are as under:

\subsection{Population trends and projections of Bangalore:}

The population of India is increasing at an alarming rate and the statistics 
reveal that our country is the second most populated country in the world. This increasing rate has made the population forecasting an important tool. The population data from the year 1951 to 2011 was collected and was then forecasted for 2021, 2031, 2041 and 2051. Arithmetic mean, geometric Mean and incremental Increase are the three methods that have been used for projecting the population of Bangalore city. The population calculated from the arithmetic mean method is assumed to be underestimated whereas overestimated when calculated using Geometric mean method. Thus, an Average value is calculated which will be further used for calculating the waste generation in the city. Table 1 , Figure 3 and Figure 4 clearly shows the population trends till 2051.

Table 1.Population trends and forecasting of Bangalore

\begin{tabular}{|c|c|c|c|}
\hline Years & Arithmetic & Geometric & Incremental \\
\hline 2021 & 9253351 & 11876639 & 9605376 \\
\hline 2031 & 10011209 & 16603458 & 11130441 \\
\hline 2041 & 10769068 & 23211518 & 13070687 \\
\hline 2051 & 11526927 & 32449541 & 15426112 \\
\hline
\end{tabular}

Figure: 4

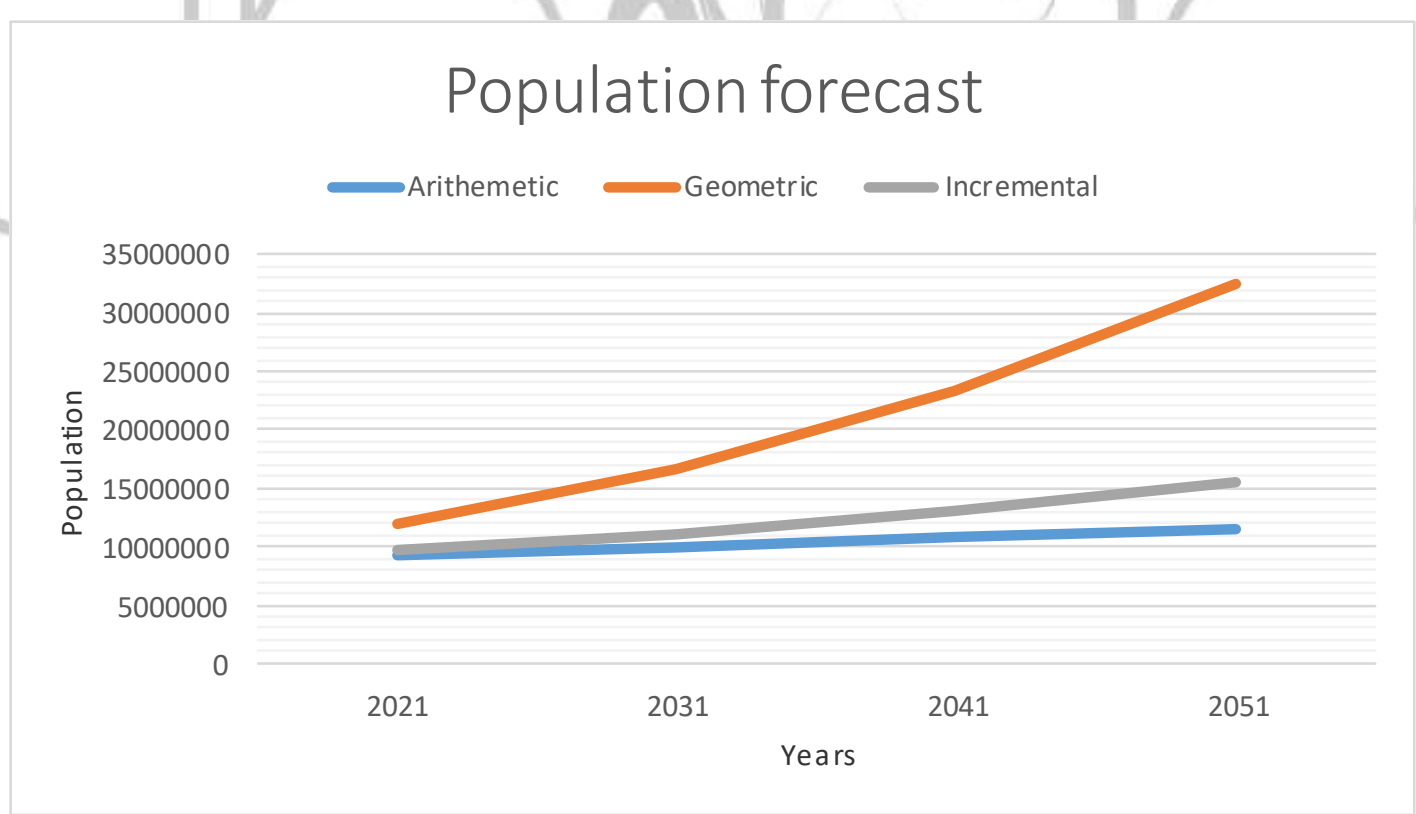

Population trends and forecasting

5.2Solid waste generation trends and projections of Bangalore:

The generating of the waste in the cities depends on various factors such as living standards, eating habits and extent of commercial activities. For the prediction of solid waste generated in Bangalore, the waste production assumed is $1 \mathrm{~kg} / \mathrm{capita} /$ day for the year 2021. This is higher than the general value assumed as it takes into 
consideration the migrant laborers. Due to the migrations, changes in the lifestyle and increasing urbanization the waste production in $\mathrm{kg} /$ capita/day have increased by 0.1 for the coming decades. The solid waste assumed rate is shown in figure 4 and waste generation over past decades and for the upcoming decades is mentioned in Table 2 and depicted in Figure5.

Figure 5: Waste per capita per day over different decades

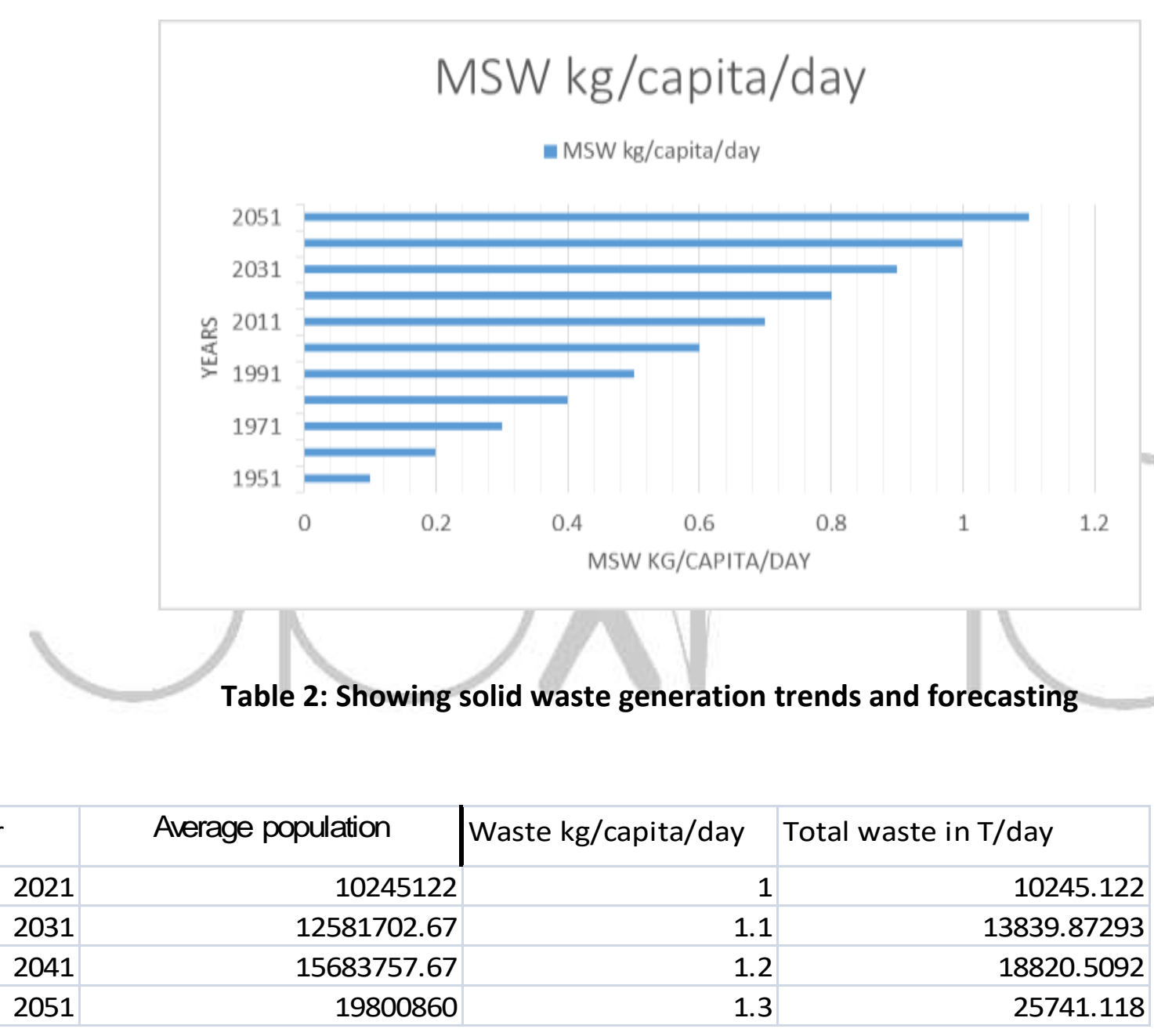

Figure 6 Waste generation trends and forecasting 


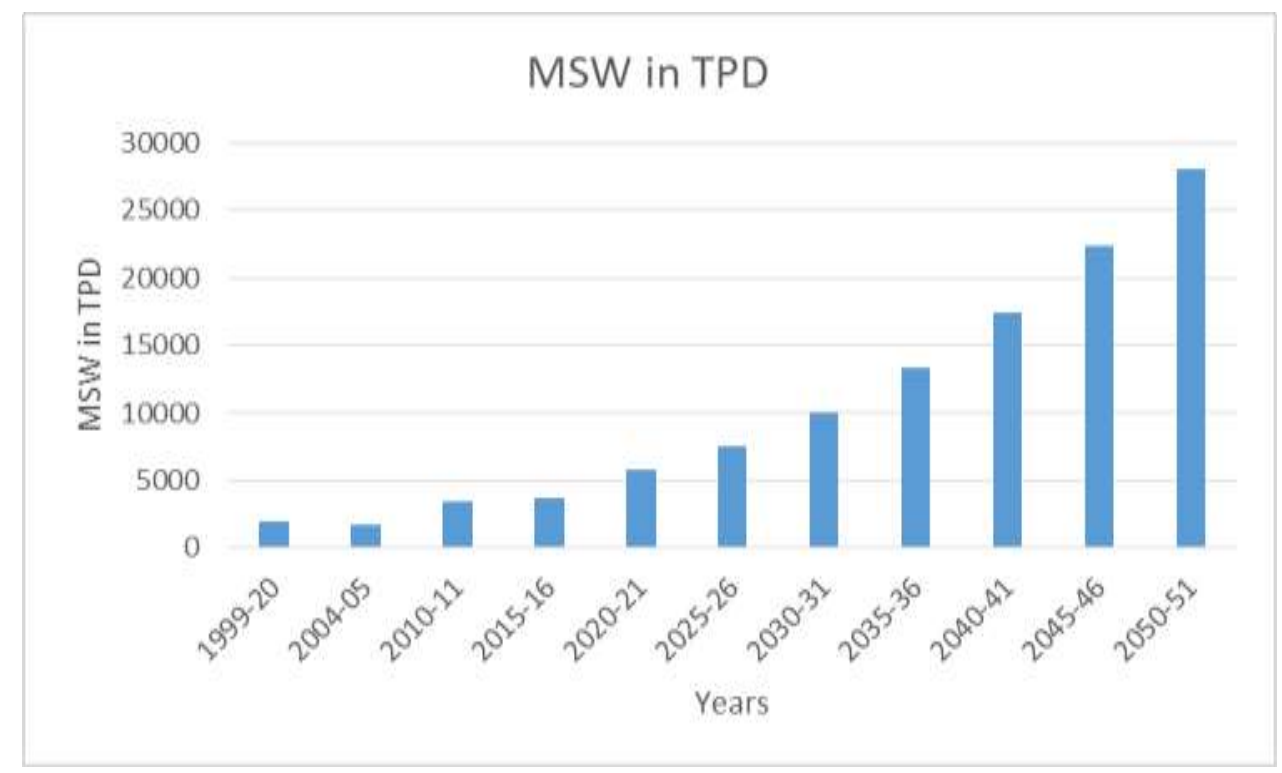

5.3 Production of compost, bio fuel and power from waste:

Various reports were analyzed and the following assumptions were made for the calculations of the compost, biofuel and energy produced from 1000 tons of waste. In India, The amount of highly calorific value waste accounts to only $15 \%$ of the total waste which can be incinerated in order to produce energy. Accordingly, based on assumptions, following can be produced from 1000 tons of waste

- BIO GAS PRODUCTION $=21.43 \mathrm{~m}^{3}$

- $10 \mathrm{mw}$ power generation

- Compost = 81.43 tons

Figure 6, 7 and 8 clearly depicts the compost, bio-fuel and energy that can be produced for the coming decades. Table 3 shows the waste to compost, energy and bio-fuel production.

Table 3. Showing Waste to Compost, Bio-fuel and Energy Production

\begin{tabular}{|r|r|r|r|r|}
\hline year & Total waste in T/day & Biogas in M3/day & Compost T/day & Power in MW/day \\
\hline 2021 & 10245.122 & 219.5529645 & 834.2602845 & 15.367683 \\
\hline 2031 & 13839.87293 & 296.588477 & 1126.980853 & 20.7598094 \\
\hline 2041 & 18820.5092 & 403.3235122 & 1532.554064 & 28.2307638 \\
\hline 2051 & 25741.118 & 551.6321587 & 2096.099239 & 38.611677 \\
\hline
\end{tabular}

Figure 7: Showing waste to compost production 


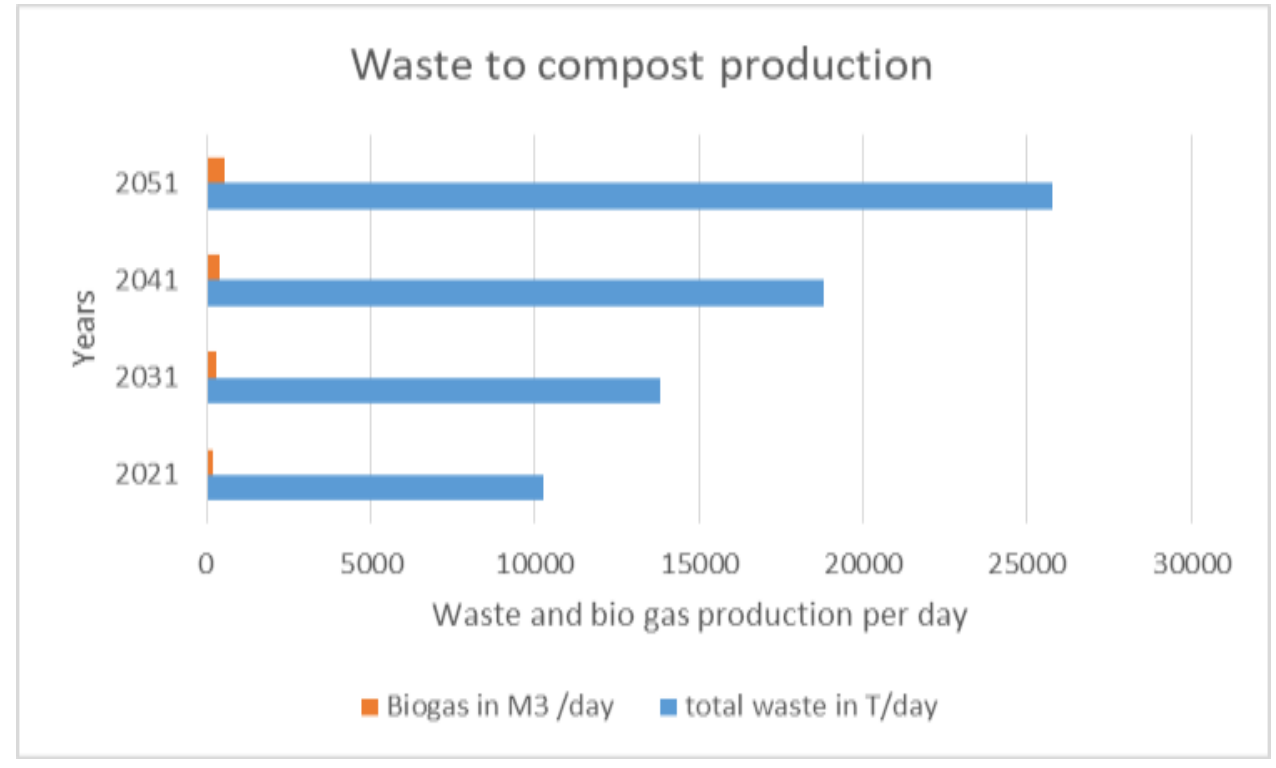

Figure 8: Showing waste to bio-fuel production

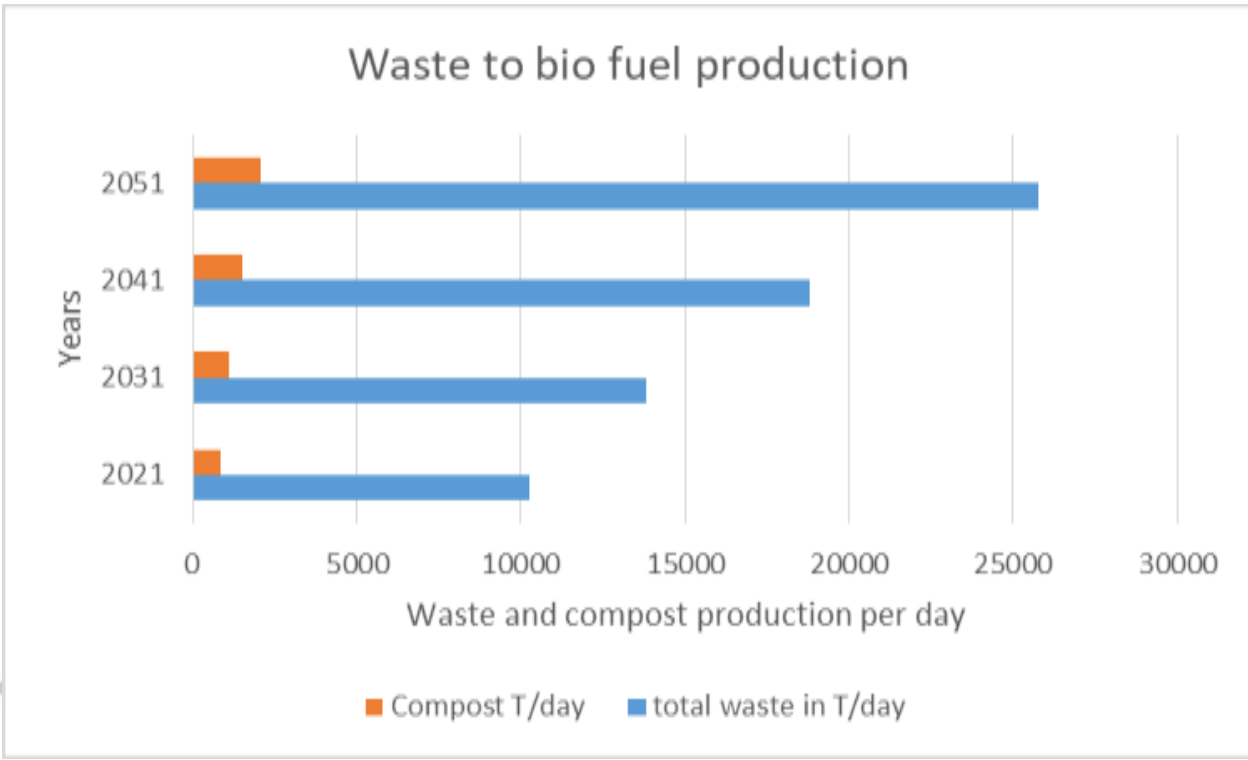

Figure 9: Showing waste to energy production

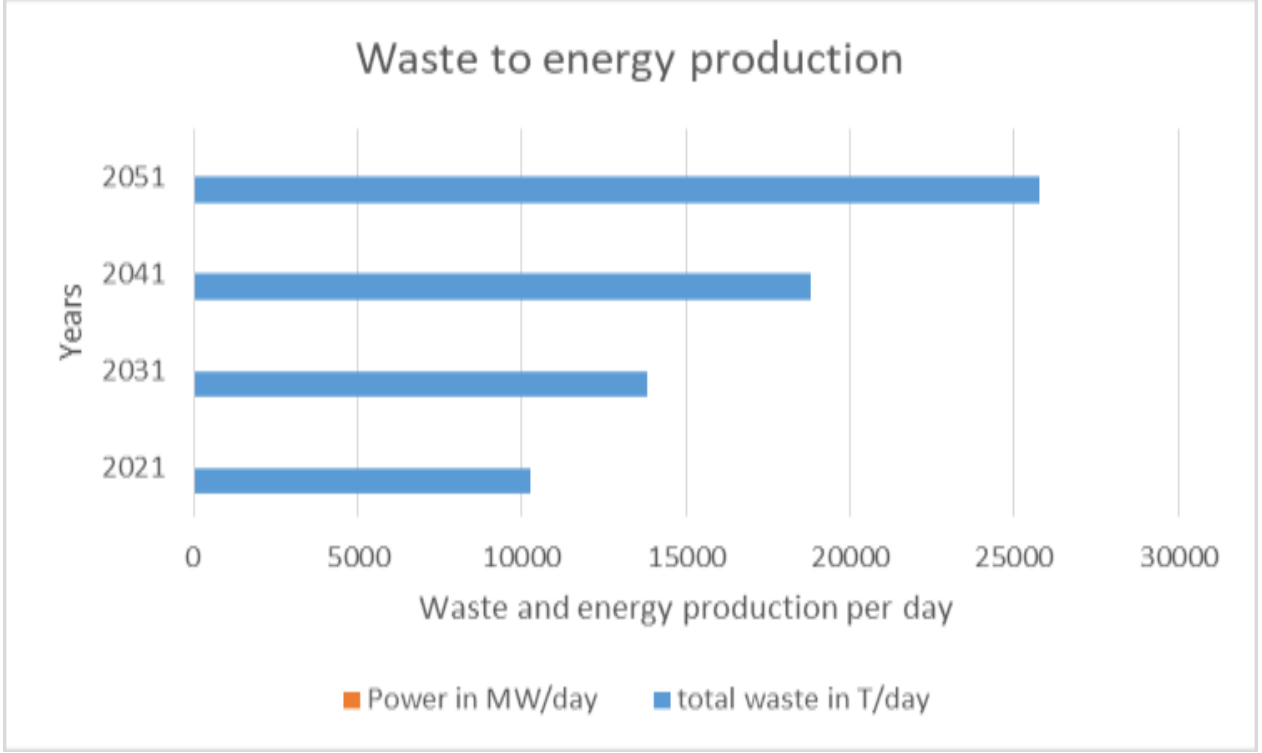

2020 November Edition | www.jbino.com | Innovative Association 


\subsection{Economic dimensions:}

The following assumptions have been made in order to calculate the total economic value.

Per ton cost of compost production as Rupees 10 which would increase in upcoming decades due to the increase in the waste generation, Hence, Rs. 5 increase have been taken per decade.
Cost of bio-fuel per liter $=$ Rs. 45

Cost of per unit Power $=$ Rs. 4

Table 4 shows the economic value calculation on converting waste to compost, energy and bio-fuel. Figure 9 and Figure 10 depicts the revenue generation from compost, bio-fuel and energy production.

Table 4. Showing the Economic Value generation from waste

\begin{tabular}{|r|r|r|r|r|}
\hline year & Compost in lac rs/day & Power in lac rs/day & Biofuel in lac rs/day & Total value in lac rs/year \\
\hline 2021 & 83.42602845 & 0.61470732 & 98.79883401 & 66736.44297 \\
\hline 2031 & 169.0471279 & 0.830392376 & 148.2942385 & 116132.692 \\
\hline 2041 & 306.5108128 & 1.129230552 & 221.8279317 & 233247.6199 \\
\hline 2051 & 524.0248097 & 1.54446708 & 330.9792952 & 312640.2288 \\
\hline
\end{tabular}

Figure 10. Revenue Generation from Compost And Bio-Fuel Production

Revenue generation from compost and biofuel production

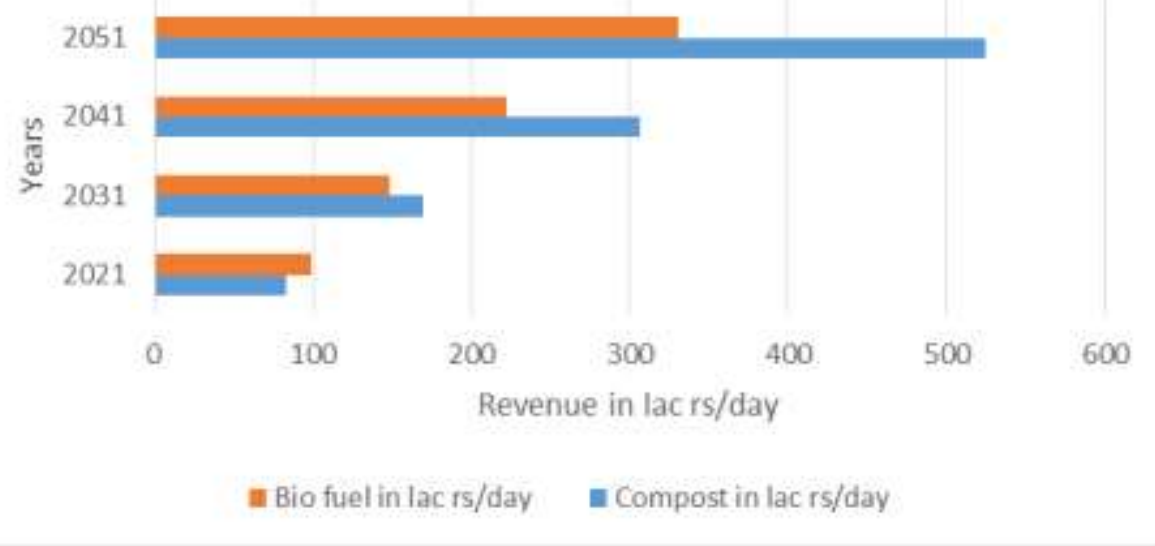

Figure11. Revenue Generation from Energy Production 


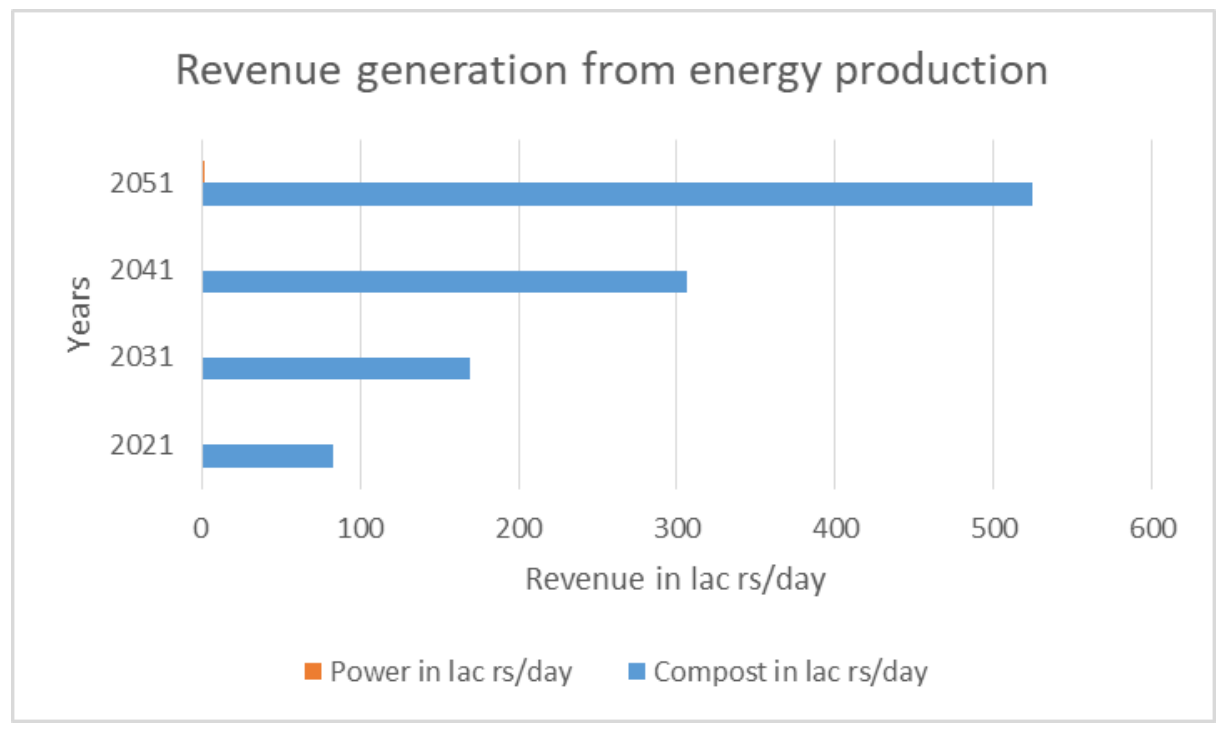

\section{Conclusion:}

With the emerging problem of indiscriminate disposal of municipal solid waste and consequential environmental pollution to a great extent, there is an urgent need it to demonstrate environmentally sustainable management of municipal solid waste. Such a management strategy should be formulated for the next 30 years to make it sustainable on a time scale. The present paper highlights a case study of Bangalore wherein trends of population and solid waste generation from 1951 to 2051 were estimated. Technological options were also briefly described for transformation of waste to usable products. Accordingly, it has been estimated that how much quantity of compost, bio fuels and energy that can be produced from waste generated in Bangalore on a time scale coupled with economic value likely to be generated from such products. It would thus be apparent that presently revenue to the extent of 6673 million rupees can be generated from the waste which may reach to 31264 million rupees in the year 2051. Such a significant amount can not only be used for effective waste management in the city of Bangalore but also minimize pollution to a great extent. However, segregation of waste preferably at source or otherwise at the disposal site should be carried out to make best use of degradable and non degradable wastes separately. Moreover, effective strategy formulation, commitments, use of best technological options and implementation would surely achieve environmentally sustainable management of municipal waste.

\section{References}

1. Kaza, S., Yao, L., Bhada-Tata, P., \& Van Woerden, F. (2018). What a waste 2.0: a global snapshot of solid waste management to 2050. The World Bank.

2. Gupta, S., Mohan, K., Prasad, R., Gupta, S., \&Kansal, A. (1998). Solid waste management in India: options and opportunities. Resources, conservation and recycling, 24(2), 137-154.

3. Eriksson, O., Reich, M. C., Frostell, B., 
Björklund, A., Assefa, G., Sundqvist, J. O., ...\&Thyselius, L. (2005). Municipal solid waste management from a systems perspective. Journal of cleaner production, 13(3), 241-252.

4. Henry, R. K., Yongsheng, Z., \& Jun, D. (2006). Municipal solid waste management challenges in developing countries-Kenyan case study. Waste management, 26(1), 92-100.

5. Rathi, S. (2006). Alternative approaches for better municipal solid waste management in Mumbai, India. Waste management, 26(10), 1192-1200.
6. Zia, H., \&Devadas, V. (2008). Urban solid waste management in Kanpur: Opportunities and perspectives. Habitat international, 32 (1), 58-73.

7. Acurio, G., Rossin, A., Teixeira, P.F., and Zepeda, F. (1998). Diagnosis of municipal solid waste management in Latin America and the Carribbea, Joint publication of the Inter-American.

8. Waste scavenging in third world cities: A case study in Ilorin, Nigeria. The Environmentalist 21, 93. Afon, A.O., and Okewole, A. (2007). Estimating the quantity of solid waste generation in Oyo, Nigeria. 